
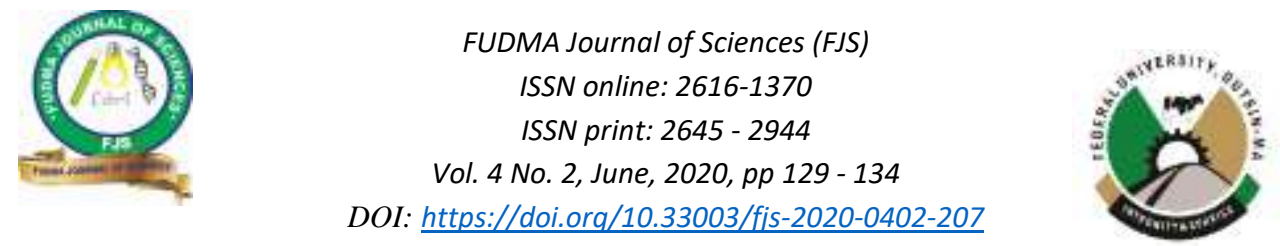

\title{
ECONOMIC ANALYSIS OF MARKETING WHITE SKINNED SWEET POTATO (Ipomoea batatas) IN SELECTED MARKETS OF KANO STATE, NIGERIA.
}

\author{
${ }^{1}$ Balarabe, Z. A., ${ }^{2}$ Yaro, A. M., ${ }^{2}$ Yakubu, S. A., ${ }^{2}$ Shu'aib, A. U., ${ }^{2}$ Safiyanu, S. A. and ${ }^{2}$ Aliyu S. A. \\ ${ }^{1}$ Science and Technical School Management Board, Kano State. \\ ${ }^{2}$ Department of Agricultural Economics and Extension, Kano University of Science and Technology, Wudil, Kano State, Nigeria. \\ Corresponding author's email: zakariyyab@gmail.com salmansufyan1983@gmail.com, Phone No.+234-8036889976
}

\begin{abstract}
The study focused on the analysis of marketing White skinned Sweet Potato in selected markets of Kano State. Multistage sampling techniques was used for the study and data was collected using a structured questionnaire supplemented with key informant interview. A total of one hundred and seventeen 117 white sweet potato marketers were sampled. The analytical tool employed included simple descriptive statistics, net marketing margin, Gini Coefficient, marketing efficiency and multiple regression of the respondents in the study area. The result of the socio economic characteristics showed that $33 \%$ of the white sweet potato marketers were adult belonging to the age group of 30-39 years, $60 \%$ of marketers had household size of 1-10 members, $41 \%$ had 1-10 years of marketing experience, $91 \%$ were married with $91 \%$ males, the result of educational background study area shows that $46.8 \%$ had informal education. The result of the profitability analysis revealed that white sweet potato marketing was profitable with $\$ 574.52$ and the total revenue realized for the marketing were $\$ 3,829.06$. The result further revealed Gross Margin (GR) of 0.85 traded in the study area while return per naira invested was found to be 1.18 accrued from every 1.00 invested. The result also revealed that marketing of white sweet potato was efficient with $225.27 \%$. The study further revealed variables such as: marketing experience, labour costs, transportation costs, loading and off-loading were found to be statistically significant. Results also indicate that the major determinant of net marketing income in the study area included labour cost, experience and transportation cost. The study recommended that since white sweet potato marketing determined to be a profitable enterprise more should and enhance income generations in the study area.
\end{abstract}

Keywords: Multistage sampling, potato, descriptive statistics, profitable analysis, marketing

\section{INTRODUCTION}

Sweet potato (Ipomoea batatas) is an important tropical crop which belongs to the morning-glory family known as convolulaceae that originated from Latin America, it ranks second after cassava among the tropical root crops International Potato Center (IPC, 2011). The crop can be considered in promoting nutritional security particularly in agriculturally backward areas, beside carbohydrates it is a rich source of protein, lipids, calcium and carotene (Low et. al., 2009). It has been used in Africa to combat a widespread of vitamin A deficiency which causes blindness and even death in 25,000 500,000 children per year (Low et al 2009). Despite the demographic pressure on land, there has been noticeable increase in the production of sweet potato in Nigeria (Low et. al., 2009). Sweet potato (Ipomoea batatas L.) is an important traditional crop that is grown customarily by small-scale farmers mainly for household consumption. It ranks as the seventh most important food crop in the world after wheat, rice, maize, potato, barley, and cassava with a global annual production of over 133 million tons (Ali et. al.2017). It is an important root crop that provides food to a large segment of the world population, especially in the tropics and subtropics where bulk of these crops are cultivated and consumed. Asia is the largest sweet potato producing region with 125 million tons of annual production (Abegunde and Arogundade, 2012). Sweet potato production rose from 2.516 million metric tons in 2006 to 3.4 million metric tons in 2007 and China accounts for about $90 \%$ of worldwide sweet potato production with an annual production of 117 million tons (Srinivas, 2006 and Akoroda, 2009. The surveys conducted revealed that there is an increase of sweet potato production by $2.65 \%$ from $2008-2009$ in Zone III which comprised 17 Local Governments (KNARDA, 2010). These increases were attributed to improved technological inputs, international and national research efforts. FAO, (2013) asserted that an increased sweet potato production that is not matched by adequate promotion and marketing to absorb surpluses from increased field has been detrimental to the sustainability of sweet potato production in the study area. According to International Potato Center IPC, (2011), 7 million tons are produced in Africa annually, mostly for human 
consumption. However, African yields are quite low about a one third of Asian yields indicating huge potential for future growth (Mmasa et al., 2011). In East Africa, sweet potato is the main food crop in many rural areas. It forms $50 \%$ of rural household incomes in the region. The most common varieties grown are: white, red, purple and the yellow-fleshed sweet potato. Preparation of sweet potato food is commonly done by boiling, baking, frying or roasting the unprocessed tubers; however, vines are fed to livestock particularly in areas like central Kenya where small-scale dairying in zero grazing management systems is well developed (Mmasa et. al., 2011). According to Mukras, (2013) sweet potato is an under-exploited food crop in East Africa. The limited range of ways and availability of adapting processing technologies in which sweet potato is utilized in the region seriously undermine its potential benefits to farmers, consumers and other chain actors (Mmasa et,al., 2011).

\section{MATERIAL AND METHODS}

The study was carried out in Kano State, Nigeria.

\section{Sampling Techniques}

A multistage sampling technique was used for data collection in the study area. The first stage involves purposive selection of one local government area from each zone based on relative abundance and high intensity of sweet potato marketing. On that basis Kibiya Local Government was chosen from zone I, Rimin Gado Local Government was chosen from zone II and Wudil Local Government was chosen from zone III. The second stage, involves purposive selection of one market from each of the selected local governments based on the size, location and high involvement in white sweet potato marketing. On that basis, Kibiya market was selected from zone I, Rimin Gado markets was selected from zone II and Darki market was selected from zone III. The third stage, involves random selection of respondents from the three selected markets. A pre-survey was conducted and a total of 389 marketers were identified from all the markets out of which $30 \%$ was considered from each of the selected markets, due to financial and time constraint. In the last stage, a total of 117 white sweet potato marketers were randomly selected for the study.

Analytical Tools: The tools of analysis used for this study are: Descriptive statistics, Marketing margin analysis and Marketing Efficiency.

Marketing Margin Analysis: The model is specified as follows:

Net Marketing Margin $(\mathrm{NM})=\mathrm{TR}-\mathrm{TMC}$

Where:

$\begin{array}{cl}\mathrm{NMM}= & \text { Net Marketing margin } \\ \mathrm{TMC}= & \text { Total }\end{array}$

Where: $\mathrm{C}_{1}=$ Cost of Transportation $\mathrm{C}_{2}=$ Cost of labor $\mathrm{C}_{3}$ $=$ Marketing charges $\# \quad \mathrm{C}_{4}=$ Storage $\#$ and $\mathrm{C}_{5}=$ Commission Fee

Gross Ratio: It is a ratio that measures the overall financial success of a business. A less than 1 ratio is desirable for any business, the lower the ratio the higher the profit (Olukosi and Erhabor, 2008). It is stated as:

GR= TMC- - - - - - - - - - - (

TR

Where,

$$
\begin{aligned}
& \text { GR }=\text { Gross Ratio } \\
& \text { TMC }=\text { Total Marketing Cost } \\
& \text { TR }=\text { Total Revenue }
\end{aligned}
$$

Operating Ratio: It measures the solvency of a business. A ratio less than 1 is desirable because it indicates that the business is making profit. A ratio of 1 implies break-even and a ratio greater than 1 implies a loss (Olukosi and Erhabor, 2008). According to Musa et. al., (2006), the lower the ratio $(<1)$ the higher the profitability of the business. It is given as:

OR = TVC - . - . - - - (iii)

TR

Where,

$\mathrm{OR}=$ Operating Ratio, $\mathrm{TMC}=$ Total Variable Cost and $\mathrm{TR}=$ Total Revenue

Return on Capital Invested: return on capital invested is defined as total income or revenue divided by total marketing cost (Olukosi et. al., 2005). It is given as:

RNI= TR ----------------------- (iv)

TMC

Where,

$\mathrm{RNI}=$ Return on Capital Invested

$\mathrm{TR}=$ Total Revenue

$\mathrm{TMC}=$ Total Marketing Cost

Marketing Efficiency: The formula is specified as:

M.E = Value added by marketing X 100 - (vi)

Cost of marketing services

Thus:

Value Added by marketing $(\mathrm{VA})=\mathrm{Sp}-\mathrm{Pp}$

Where:

$\mathrm{Sp}=$ Selling price of the commodity (A)

$\mathrm{Pp}=$ Purchase price of the commodity (

\section{Multiple Regression Model}

Multiple regression was employed to achieve objective iii (socio-economic factors influencing the profitability of sweet potato marketing in study area). The profit margin was the dependent variable and the independent variables were identified and specified in the general model as it was used by (Shua'ib et. al., 2011).

The implicit model is; 
$\mathrm{Y}=\mathrm{f}\left(\begin{array}{llllllll}\mathrm{X}_{1} & \mathrm{X}_{2} & \mathrm{X}_{3} & \mathrm{X}_{4} & \mathrm{X}_{5} & \mathrm{X}_{6} & \mathrm{X}_{7} & \mathrm{X}_{8} \ldots \ldots \ldots \mathrm{xn}\end{array}\right)+\mathrm{e}$ (ix)

Where,

$\mathrm{Y}=$ Profit/150kg sold ( $)$

$\mathrm{X}_{1}=$ Age of Potatoes Marketers (years)

$\mathrm{X}_{2}=$ House hold size of Potatoes Marketers (number of persons)

$\mathrm{X}_{3}=$ Educational Status of Potatoes Marketers (1-tertiary inst.,

2-sec., 3-pri., 4-others)

$\mathrm{X}_{4}=$ Gender of Potatoes Marketers (1-male, 2-female)

$\mathrm{X}_{5}=$ Transportation cost $(\mathrm{A})$

$\mathrm{X}_{6}=\operatorname{Tax}(\mathrm{N})$

$\mathrm{X}_{7}=$ Loading and off-loading $(\mathrm{N})$

$\mathrm{X}_{8}=$ Time spent in the Market (Hours)

$\mathrm{X}_{9}=$ Type 1 . White, 2. Red, 3. Purple.

$\mathrm{U}=$ error term

$\alpha=$ constant

$\mathrm{f}=$ functional notation

\section{RESULTS AND DISCUSSION}

Socio Economic Characteristic of Respondents

The distributions of respondents according to age as presented in Table 1 revealed that $33 \%$ of the sweet potato marketers were within the age range of 30-39 years with a mean of 37 years, implying that the marketers were strong, agile and active and can participate adequately in marketing activities. Age is expected to have negative influence on the respondent's participation in improved sweet potato marketing. This agrees with the findings of Okwuokenye and Onemolease (2011) that age can influence the adoption of improved agricultural practices. The findings are also consistent with those of Mbanaso et. al., (2012). Funke, Raphel and Kabir (2012), Tiri, Ekpa and Akinyemi (2015) and Gichangi, (2010) reported that the most active marketers' age group engaged in agricultural production was within 31- 50 years. Table 1 further indicates that sweet potato market is male dominant with a proportion of $98.25 \%$. The results of the marital status of sweet potato marketers showed that majority of the marketers $(76.92 \%)$ were married while $(21.37 \%)$ of the marketers were single. Ikechi, (2005) argues that marriage has a direct relationship with family stability; therefore, the high percentage of married respondents suggested that the sweet potato marketers were stable and able to make good business decisions. The result in Table 1 below shows that $46.8 \%$ of sweet potato marketers had no formal education, about $41.3 \%$ of the respondent had only primary education, and $3.2 \%$ had secondary education while $1.6 \%$ had tertiary education. This indicates that the marketers' educational level is high. This high literacy proportion of sweet potato marketers in the study area implied that the marketers would be better exposed to more reliable information sources and good decision making in their marketing activities. This finding is in line with Esiobu and Onubuogu (2014) which found that education has a positive and significant impact on marketers' efficiency. Thus, literacy level will greatly influence the decision making and adoption of innovation by marketers, which may bring about increase in productivity.

Profitability of Marketing White Sweet Potato

Net marketing returns of white sweet potato marketers were presented in Table 2. The result of net marketing returns of white sweet potato sold per week in kg showed that the white sweet potato enterprise was viable. It was observed that the mean weight of 1 bag of white sweet potato weighed $150 \mathrm{~kg}$. The average selling price for a $\mathrm{kg}$ of white sweet potato was \#3,829.06 while the average purchasing price was $\$ 2,808.55$. The mean marketing returns made by the white sweet potato marketers per week were $\$ 574.52$.

The result in Table 3 also revealed that white sweet potato purchase price cost accounted for $86.3 \%$ of the total cost while cost of transportation accounted for $8.4 \%$ of the total cost. The Table also showed that the cost of labour gulped $3.2 \%$ of the total cost while marketing charges accounted for $2.1 \%$ of the total cost. The low marketing charges among the marketers may be due to the fact that most of them sell in open spaces, along the road where stalls are allocated to other food stuff sellers or pay for a section of another person's shop. The Table also revealed that an average marketer incurred a total variable cost of $\$ 3,254.54$ per week but earned average revenue of $\$ 3$, 829.06 per week. This indicates that average marketer earned \#574 as gross margin per week suggesting that white sweet potato marketing is a profitable venture in the study area. The average rate of return on investment (return per naira invested) was $\mathrm{N1}$ 1.18, indicating that for every $\mathrm{N} 1$ invested in white sweet potato in the study area a profit of 18 kobo was made. Thus, it could be concluded that white sweet potato market in the study area is profitable. This finding is consistent to the findings of Elizabeth (2013) who observed that sweet potato marketing is profitable by returning $\$ 0.40$ to every 1.00 spent.

\section{Marketing efficiency per $150 \mathrm{~kg}$ of white sweet potato.}

The results in Table 3 shows the marketing efficiencies of white sweet potato was found to be $288.58 \%, 175 \%$ and $212.14 \%$ for Kibiya, R/Gado and Darki markets respectively. The results revealed that all the markets were efficient in white sweet potato marketing with Kibiya market having the higher marketing efficiency. The higher the ratio the higher the marketing efficiency and vice versa (Olukosi, et. al., 2007).

\section{Factors Affecting Profitability of White Sweet Potato}

The results of regression analysis presented in Table 4 shows a significant of $\mathrm{R}=0.800$. This implies that multiple regression coefficients between the predictors and the criterion was $80 \%$, A summary of the model presented in Table 4 shows the adjusted coefficient of determination of $\mathrm{R}^{2}$ value of 0.640 . This indicates that $64 . \%$ of the variation in the profitability of white sweet potato is explained by the independent variables. Furthermore, it indicates that $36.0 \%$ of the variations in the profitability of white sweet potato are determined by other 
factors not considered. The factors not considered can include climatic conditions of the area; distance to various possible markets; requirements in possible available markets' and the amount of time marketers spend in the market. The F-value of a model which determines the overall significance of the entire model was 21.331 and was significant at $1 \%$ level of significance. This implies that all variables included in the model were collectively important and responsible for the variation in the dependent variable of the model.

Table 1: Socio Economic Characteristics of White Sweet Potato Marketers.

\begin{tabular}{lll}
\hline Variables & Frequency & Percentage \\
\hline Age & 1 & 0.8 \\
$20-29$ & 42 & 33.3 \\
$30-39$ & 1 & 0.8 \\
$40-49$ & 38 & 30.2 \\
$50-59$ & 35 & 27.8 \\
$60-69$ & $\mathbf{1 1 7}$ & $\mathbf{1 0 0}$ \\
Total & & \\
Gender Distribution & 115 & 98.29 \\
Male & 2 & 1.71 \\
Female & 117 & 100 \\
Total & 1 & 0.8 \\
$31-40$ & $\mathbf{1 1 7}$ & $\mathbf{1 0 0}$ \\
Total & & \\
Marketing experience & 51 & 40.5 \\
$0-13$ & 41 & 32.5 \\
$11-20$ & 24 & 19.0 \\
$21-30$ & 1 & 0.8 \\
$31-40$ & $\mathbf{1 1 7}$ & $\mathbf{1 0 0}$ \\
Total & & \\
\hline
\end{tabular}

Source: Field survey, 2018.

Table 2: Computation of Gini Coefficient per $150 \mathrm{~kg}$ bag of White Sweet Potato

\begin{tabular}{|c|c|c|c|c|c|c|c|}
\hline $\begin{array}{l}\text { Quantity of } \\
\text { S/P sold/bag }\end{array}$ & $\begin{array}{l}\text { No. of S/P } \\
\text { Sellers }\end{array}$ & $\begin{array}{l}\text { Proportion of } \\
\text { S/P sellers }(\mathbf{X})\end{array}$ & $\begin{array}{l}\text { Cumulative } \\
\text { Proportion of } \\
\text { S/P sellers }\end{array}$ & $\begin{array}{l}\text { Total Value } \\
\text { of Sales }\end{array}$ & $\begin{array}{l}\text { Proportion of } \\
\text { total sale }\end{array}$ & $\begin{array}{l}\text { Cumulative } \\
\text { Total Volume } \\
\text { of Sale }(\mathbf{Y})\end{array}$ & $\Sigma X Y$ \\
\hline $1-5$ & 15 & 0.128 & 0.128 & 56,800 & 0.127 & 0.127 & 0.016 \\
\hline $6-10$ & 63 & 0.538 & 0.668 & 240,700 & 0.538 & 0.665 & 0.289 \\
\hline $11-15$ & 15 & 0.128 & 0.796 & 59,300 & 0.132 & 0.797 & 0.017 \\
\hline $16-20$ & 0 & 0.000 & 0.796 & 0.0000 & 0.000 & 0.797 & 0.000 \\
\hline $21-25$ & 24 & 0.205 & 1.000 & 91,200 & 0.204 & 1.000 & 0.042 \\
\hline $26-30$ & 0 & 0.000 & & 0.0000 & & & 0.000 \\
\hline Total & 117 & & & 448,000 & & & 0.364 \\
\hline GC & 0.6362 & & & & & & \\
\hline
\end{tabular}

Source: Field Survey (2018) Gini Coefficient 1-0.364=0.6362 
Table 3: Costs and Return of White Sweet Potato/150kg

\begin{tabular}{lll}
\hline Variables & Price $(\mathrm{N})$ & Percentage $(\%)$ \\
\hline Average Selling Price(N) & 3829.06 & \\
Variable Cost $(\mathrm{N})$ & & 86.296 \\
Sweet Potato Purchase Price & 2808.55 & 8.435 \\
Transportation & 274.53 & 3.153 \\
Labour & 102.61 & 2.116 \\
Marketing Charges & 68.85 & 100 \\
Total Marketing Cost & 3254.54 & \\
Marketing Margin & 574.52 & \\
Gross Ratio & 0.85 & \\
Operating Ratio & 0.12 & \\
Return on Capital Invested & 1.18 & \\
\hline
\end{tabular}

Source: Field Survey (2018)

Table 4: Regression Results of Factors Affecting White Sweet Potato Profitability

\begin{tabular}{|c|c|c|c|c|c|}
\hline Variables & Beta & $\mathbf{T}$ & Sig & err & Expected Sign \\
\hline Age & 0.723 & 1.140 & 0.257 & & + \\
\hline Household Size & 4.396 & 5.810 & 0.000 & & - \\
\hline Education & 1.571 & 5.248 & 0.000 & & + \\
\hline Experience & 1.359 & 1.414 & 0.160 & & + \\
\hline Transportation & -1.708 & -4.768 & 0.000 & & - \\
\hline Labour & 5.826 & 2.316 & 0.022 & & - \\
\hline Loading & -4.045 & -1.874 & 0.006 & & - \\
\hline Off-loading & -4.607 & -3.782 & 0.000 & & - \\
\hline Tax & 3.103 & 7.838 & 0.000 & & - \\
\hline $\mathbf{R}$ & 0.800 & & & & \\
\hline $\mathbf{R 2}$ & 0.640 & & & & \\
\hline Adjusted R2 & 0.610 & & & & \\
\hline $\mathbf{F}$ & 21.33 & & & & \\
\hline
\end{tabular}

Predictors: (Constant), Experience, Labour, Education, Age, Tax, Transport, Uploading, Loading, HSize

Dependent Variable: White Sweet Potato Profitability

Source: Computed from survey data

\section{CONCLUSION}

Sweet potato marketing is a profitable business with attractive net return on investment in all the markets in the study area. The research on the economic analysis of marketing white skinned sweet potato in selected markets of Kano state showed that the sweet potato marketing in the area is competitive with relatively high level of income inequality among the marketers. The study was also able to show that considerable number of factors militates against an effectual marketing structure of the crop

\section{RECOMMENDATION}

Based on the findings of this study, it is recommended that: I. Sweet potato marketers should form a cooperative group in order to obtain loan from the financial institutions to increase their capital base: loan will be easily acquired from these cooperatives without bureaucratic bottlenecks.
II. Also government should provide an enabling environment through the provision of needed infrastructural facilities especially good roads.

III. Since the coefficient of labour and experience were positive and significant, it implies that through labour and experience, some marketers may learn more about the prevailing market conditions. This learning by experience should be enhanced through training of the marketers by the non-governmental and government agencies, on the existing and potential sweet potato market opportunities such as sourcing and marketing of highly competitive sweet potato varieties and storage management techniques.

\section{REFERENCES}

Agbugba, I. K. (2014). Marketing of Dry Season Vegetables in South-East Nigeria. A Ph.D. Thesis University of Nigeria, Nsukka. 
Ali, O., Nyiatagher, Z.T. \& Monica, U. (2017). Economic Analysis of Sweet Potato Marketing in Benue State, Nigeria. Journal of Research in Business and Management5(7), 41-47

Central Bank of Nigeria (1999): CBN Annual Report of 1998, Lagos Nigeria, Vol.10 Pp 41.

Esiobu, N., \& Onubuogu, G. (2014). Socio-economic Analysis of Frozen Fish Marketing in Owerri municipal council area, Imo State, Nigeria: An Econometric Model Approach. Journal of Agricultural Science, 4(8), 449-459.

Food and Agriculture Organization (2003) Food and Agriculture Organization United Nations, Production Year Book, Vol 39, Rome.

Food and Agriculture Organization (2013). FAO Production Year Book: FAOSTAT, Volume 49, No. 130. pp 39-41.

Funke, O., Raphel, B. \& Kabir, S. (2012). Market Structure, Conduct and Performance of Gari Processing Industry in South Western Nigeria. European Journal of Business and Management, 4(2), 99-116.

Federal Republic of Nigeria, (2007). Official Gazette. No24 Volume 94 Published by the Federal Government Printer, Lagos, Nigeria.

Gichangi, A.W. (2010). Analysis of Structure, Conduct and Performance of Sweet Potato Marketing: The Case of Nairobi and Kisumu, Kenya. Master of Science Thesis Agricultural Economics of Egerton University.

IPC (International Potato Centre) Lima, Peru. (2011). Sweet potato: Treasure for the power in sweet potato main. 25 .

Ikechi K. et, al., (2005). The performance of vegetable production and marketing in Aba area, Abia State, Nigeria. Pp 133-134.

Kano State Agricultural and Rural Development Authority (KNARDA) Headquarters, Kano 2010 Bulletin. Pp 11- 19.

Kohls, R. L and Uhls, J.N. (2005): Marketing of Agricultural Products, $7^{\text {th }}$ Edition Macmillan, U.K. London.

Low et. al.; (2009) Dietary fibre and other constituents of sweet potato. J. food science 50: 1756-1757.
Mmasaet. al., (2011) Sweet potato production in South Africa, Loebenstein G and G. Spring science Business Media B.V, 2011. 564-753.

Mukras, M.S., Alphonce, O.J., Momanyi, G. (2013). Determinants of Demand for Sweet Potatoes at the Farm, Retail and Wholesale Markets in Kenya. Advances in Economics and Business, 1(2), 150-158,

National Population Commission (2006), Census Report. Pp 3035 .

Olukosi, J.O. Isitor, S.U. and Moses, O.O. (2005). Introduction to Agricultural Marketing and prices: Living Books Series G. U. Publishers, Abuja, Nigeria. Pp 46-47.

Olukosi, J.O, (2007). Introduction to Agricultural marketing and Prices: Principles and Application. $3^{\text {rd }}$ Edition Living Books Series G. U. Publishers, Abuja, Nigeria.

Okwuokenye, G.F. and Onemolease, E.A. (2011). Influence of Socio-Economic Characteristics of Yam Sellers on Marketing Margins among Yam Wholesalers in Delta State, Nigeria. Journal of Agriculture and Social Research, 11(1), 81-89

Srinivas (2006) Economics of sweet potato production and marketing, in the sweet potato. Loebenstein G. and Thottapilly, G (eds). Spring Science Business Media B.V 2009, 436-247.

Shu'aib A.U, Kyiogwom U.B, Yakasai M.T, Yaro A.M Ahmad S.Y Ismail I.S and Dahiru A. (2011). Socio economic determinants of modern Bee-keeping in Kano state, Nigeria. Proceedings of $12^{\text {th }}$ annual conference of Nigerian Association of Agricultural Economic, University of Benin, $12^{\text {th }}$ to $16^{\text {th }}$ November, 101-105.

Tiri, G.D., Ekpa, D. \& Akinyemi, M. (2015). Empirical Assessment of Factors Affecting Marketing Efficiency: A Focus on Sweet Orange Markets in Kano Metropolis, Nigeria. International Journal of Innovative Agriculture \& Biology Research,3(2), 1-9.

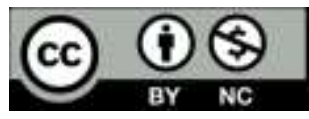

(C)2020 This is an Open Access article distributed under the terms of the Creative Commons Attribution 4.0 International license viewed via https://creativecommons.org/licenses/by/4.0/ which permits unrestricted use, distribution, and reproduction in any medium, provided the original work is cited appropriately. 